\title{
On Being Uncomfortable
}

\author{
Ruth Fletcher ${ }^{1} \cdot$ Julie McCandless $^{2} \cdot$ Yvette Russell $^{3}$. \\ Dania Thomas ${ }^{4}$
}

\begin{abstract}
Since the last issue of Feminist Legal Studies, we editorial board members have had lots of conversations about comfort, displacement and alienation. As we developed the programme for \#FLaK2016 we thought about it as a kind of pulling ourselves out of our comfort zone (Fletcher et al. in Fem Leg Stud 24:1-6, 2016), if academic events and journals ever have a comfort zone. Drawing on a mix of feminist live performance methods and a science and technology studies-type curiosity for objects of experimentation, we tried out a kitchen table method of hosting a live research conversation with activists, artists and academics over two days (Fletcher in Fem Leg Stud 23:241-252, 2015). But we had not fully anticipated the way that the Brexit result would contribute to and complicate discomfort. A fuller analysis of FLaK awaits a later moment, but here we pick out this one aspect of our gathering - feelings of discomfort - as they animate the contributions to this issue in interesting ways.
\end{abstract}

Ruth Fletcher

r.fletcher@qmul.ac.uk

Julie McCandless

j.c.mccandless@1se.ac.uk

Yvette Russell

Yvette.russell@bristol.ac.uk

Dania Thomas

dania.thomas@glasgow.ac.uk

1 Department of Law, Queen Mary University of London, Mile End Road, London E1 4NS, UK

2 London School of Economics, London, UK

3 University of Bristol, Bristol, UK

4 University of Glasgow, Glasgow, UK 
Keywords Discomfort $\cdot$ FLaK $\cdot$ Mixed methods $\cdot$ Feminist legal studies $\cdot$ Kitchen table $\cdot$ Feminism

\section{Introduction}

Since the last issue of Feminist Legal Studies, we editorial board members have had lots of conversations about comfort, displacement and alienation. Some of these conversations, like \#FLaK2016, were programmed, some were spontaneous, some were together, some were apart, some have been going on for a long time, and some were reactions to Brexit. ${ }^{1}$ As we developed the programme for FLaK we thought about it as a kind of pulling ourselves out of our comfort zone (Fletcher et al. 2016), if academic events and journals ever have a comfort zone. Drawing on a mix of feminist live performance methods and a science and technology studies (STS)-type curiosity for objects of experimentation, we tried out a kitchen table method of hosting a live research conversation with activists, artists and academics over two days (Fletcher 2015).

A fuller analysis of FLaK needs more time and awaits a later moment, but here we pick out one aspect of our gathering-feelings of discomfort-as a dimension of feminist experience, which motivates further research and activism. Being uncomfortable can be exhausting and painful, ${ }^{2}$ but it is not always, wholly or necessarily a 'bad' experience. Feeling uncomfortable has provoked feminists to find imaginative ways of talking back to loud noises, to watch for quiet or halfhidden signals, and to organize alternative ways of living. Moreover, being uncomfortable has taught us to take time to assess discomfort because its meaning is not always transparent, it is usually layered and it just might be generative.

\section{Uncomfortable Work}

In this issue, Matulewicz investigates the normalization of restaurant workers' sexualized discomfort and the implications of that for meeting legal tests of 'unwelcome conduct' in claims for sexual harassment (2016). 'The Gendered Order of Restaurant Work and Making Sexual Harassment Normal,' draws on interviews with former and current restaurant workers in British Colombia, Canada, to provide a fuller picture of harassment experiences. She argues that full-service restaurant work is structured in such a way that uncomfortable sexual experiences with customers become a regular feature of the work. Key components of restaurant work, including dressing practices, customer service, and the wage-tip relation, restrict workers' reactions and normalise their subjection to unwanted or uncomfortable sexualized and racialised interactions at work. The normality of sexualized

\footnotetext{
${ }^{1}$ For an account of Brexit that was presented at FLaK and published one week before the referendum which ultimately saw $52 \%$ of UK voters vote to leave the European Union, see El-Enany (2016).

${ }^{2}$ For an example of a critical analysis of the knowing production of discomfort in order to obstruct access to abortion, see McGuinness (2015). On the significance of affect in disabling, as well as accompanying, intellectual practice see Seigworth and Greig (2010, 23).
} 
discomfort at work makes it difficult for the legal threshold of 'unwelcome', sexualized conduct to be met. Among other things, Matulewicz's work provides an excellent example of the way women's defensive tactics of deflection and 'laughing it off' become a normalized expectation. Women bear the consequences of fixing things, not those who make them uncomfortable.

\section{Discomforting Evidence}

While evidence-based contributions to law and policy remain an important epistemological source, feminists have long been uncomfortable about the closures that operate in the generation and deployment of evidence, particularly numerical evidence (see further Merry 2016; Buss 2015). Further, as Manji reminded us at FLaK after we listened to \#pparchive, we know that lots of evidence gets left out of 'the archive', particularly by colonizing processes. Cook and Natalier contribute to these important debates by critically analyzing the ways in which evidence, including anecdotal evidence, was deployed in recent family law reform debates in Australia. They focus on the 2003 inquiry into child support that contributed directly to legislative changes made in 2006-2008. They ask 'which voices were presented as authoritative' and what counts as legitimate data. They found that both quantitative data and anecdote were used to privilege fathers' financial interests and autonomy, while women's voices and interests were marginalised. They argue that the legitimacy of data is not ascribed on the basis of its type, but rather through its relationship to gendered political interests in the 'problems' of child support. As a result they suggest that the question of "which type of data might be a more effective tool in pursuing feminist law and policy reform', is the wrong question. Rather 'we need to think about which data to use in which context... how to make the intervention in order to reveal the gendered dynamics and/or push the dialogue more towards feminist ends'.

\section{Curious Discomfort}

Barlow's 'Sketching Women' asks us to think about visual knowledge and what we see and do not see when we look at courtroom sketches (2016). Although she does not put it in these terms, there is a kind of productive and curious discomfort at work here, as she asks why these women come to be presented in this way in the sketches. Barlow contributes to a FLaK interest in multi-dimensional approaches to law (see further Davies 2008) by thinking about the particularities of sketching techniques as they render courtroom dynamics visible in particular ways for non-participants. ${ }^{3}$ She provides an interpretation of the sketches, which circulate through newspapers and on the websites of the three professional courtroom sketch artists that work in Britain, as a critical viewer who has partial information about the production of

\footnotetext{
${ }^{3}$ Our thanks to Patricia Coleman for sharing her professional insights into court sketching, see further Barlow (2016).
} 
those sketches. Since court rules preclude sketch artists from drawing in court, the sketches are produced from memory afterwards, and often work to represent the mood and detail of several court hours in one sketch. Barlow notes that drawing, as distinct from photography, has received relatively less attention as a form of producing visual knowledge of law. She calls for scholars to research further into the context and purpose of the production of criminal imagery. ${ }^{4}$ For Barlow, the court artists' interpretation, the conventions of court sketching, and motifs of female offenders as secondary actors, work together to draw on existing myths and prejudices and represent the women as listening, remorseless 'others'.

\section{Acting on Discomfort}

Kivilcum responds to current critical discomfort over the displacement of Syrian refugees by examining the damaging effects of a hostile climate on Syrian women refugees in Turkey (2016). She examines the different ways that legislation and legal inaction inflict violence on refugees. The legislation which holds them in temporary protection denies access to international protection and makes them vulnerable to violence by other actors, particularly in the camps. There is no legal accountability when women in sex and household work do not get paid, while at the same time women are secured as part of the precarious workforce out of a fear of sanction for refusing work. Kivilcum examines further how Syrian beggars have become a particular target for punishment, with the vast majority of beggars being women and children. As well as providing a significant analysis of one of the contemporary humanitarian failures of our era, Kivilcum contributes to the gendering of the legal violence literature as it addresses fear of enclosure in criminal and administrative forms. In an important acknowledgment of the ways in which academics act out of commitment to a better world (Cruz and Brown 2016), Kivilcim dedicates her article to the '2212 Turkish Academics for Peace who are currently facing prosecution for terrorist propaganda for signing a petition for peace in Turkey'.

\section{Cast Out of Comfort}

In this issue's reflection, Lammasniemi assesses the significance of a recent UKSC ruling that two single, minority ethnic mothers with six and three children respectively were not unjustifiably discriminated against when the effects of benefit caps would likely mean leaving their homes and communities of support (2016).

\footnotetext{
${ }^{4}$ Interestingly, some of the pages of the FLaK zine, contributed by Máiréad Enright, Sarah Browne and Jesse Jones, featured court sketches from Northern Ireland, see https://twitter.com/maireadenright/status/ 748490277673918464. Accessed 15 July 2016. For other zine pages circulated on twitter see https:// twitter.com/Dr_KMcLoughlin/status/748957018459963392 and https://twitter.com/nataliesquared/status/ 748884386146316288.
} 
She draws out the significance of the decision in $R$ [on the application of $S G$ and others (previously JS and others)] $v$ Secretary of State for Work and Pensions [2015] UKSC 16 at three different levels. It demonstrates the terrible impact of governmental welfare policy, such as benefit caps, on single mothers, BME women and women who are escaping domestic violence, and provides further evidence that welfare recipients are devalued and regarded as non-productive even when raising future citizens in difficult circumstances. The SC 3/2 majority decision showed that the court was prepared to find that government objectives such as changing the behaviour of welfare recipients and enhancing public trust in the welfare system were sufficient to justify clear indirect discrimination on grounds of gender. (That such objectives lack an objective evidence base, in the senses that welfare is not a matter of individual behavior and that public opinion of welfare is often misinformed, did not seem to trouble the court or the Department of Work and Pensions). The SC reasoning was also significant in its consideration of international obligations on children's rights under the UN Convention of the Rights of the Child, which has not been made part of domestic law, and their interaction with rights obligations under the ECHR, which is part of domestic law. Lammasniemi notes in particular that the judicial failure to consider the minority ethnic dimensions of the claimants' lives was 'remarkable' and we would add, part of a pattern, of failing to take some people's homes and basic comforts as seriously as others.

\section{Critiquing (Dis)Comfort}

The book reviews in this issue contextualize recent contributions to feminist legal studies and critical interdisciplinary legal studies more generally. Cameron finds Keenan's Subversive Property, with its emphasis on stories that stick to subjects in spaces of belonging, a refreshing change from the usual property law obsessions with 'efficient lawyering' (2016). Levers comments that Duramy demonstrates the value of contextual understandings of gender-based violence in Gender and Violence in Haiti by expanding the current scholarship on armed conflict (2016). Marti shows how Meghani's collection of ten multi-jurisdictional essays in Women Migrant Workers contributes to an understanding of migrant domestic workers as neoliberalism's 'ideal' workers: at an employer's disposal and disposable when no longer needed (2016). Lloyd finds a subtle politicization embedded in Constable's account of performative legal speech acts in Our Word is our Bond, as it develops the oppositional methodology of Just Silences in order to investigate how law is 'said and unsaid, heard and unheard, in claims and counterclaims made by persons who participate in law' (2016).

As FLS continues to reflect on the different elements of the live research conversation that is FLaK, and where it will take us, we welcome new contributions. Does your research, including research-led practice, address mixing, mixed methods of enquiry, kitchen table and equivalent formats, decolonizing techniques, legal know-how, dissent, curation or publishing from feminist and feminist-friendly perspectives? If so, we are eager to hear from you. You can submit work in the form 
of an original article, a reflection on practice, a critical note on a legal development, or a review of new work here. ${ }^{5}$

\section{References}

Barlow, Charlotte. 2016. Sketching women in court: The visual construction of co-accused women in court drawings. Feminist Legal Studies. doi:10.1007/s10691-016-9310-3.

Buss, Doris. 2015. Measurement imperatives and gender politics: An introduction. Social Politics 22(3): 381-389. doi:10.1093/sp/jxv030.

Cameron, Angela. 2016. Review of Sarah Keenan. Subversive property: Law and the production of spaces of belonging. Feminist Legal Studies. doi:10.1007/s10691-016-9321-0.

Cook, Kay, and Kristin Natalier. 2016. Gender and evidence in family law reform: A case study of quantification and anecdote in framing and legitimising the 'problems' with child support in Australia. Feminist Legal Studies. doi:10.1007/s10691-016-9317-9.

Cruz, Katie, and Wendy Brown. 2016. Feminism, law, and neoliberalism. Feminist Legal Studies 24(1): 69-89. doi:10.1007/s10691-016-9314-z.

Davies, Margaret. 2008. Feminism and the flat law theory. Feminist Legal Studies 16(3): 281-304. doi:10. 1007/s10691-008-9096-z.

El-Enany, Nadine. 2016. Brexit as Nostalgia for Empire. Critical Legal Thinking 19 June. http:// criticallegalthinking.com/2016/06/19/brexit-nostalgia-empire/. Accessed 30 July 2016.

Fletcher, Ruth, Julie McCandless, Yvette Russell, and Dania Thomas. 2016. Internationalism and commitment at the kitchen table. Feminist Legal Studies 24(1): 1-6. doi:10.1007/s10691-016-9318-8.

Fletcher, Ruth. 2015. FLaK: Mixing feminism, legality and knowledge. Feminist Legal Studies 23(3): 241-252. doi:10.1007/s10691-015-9306-4.

Kivilcim, Zeynep. 2016. Legal violence against Syrian female refugees in Turkey. Feminist Legal Studies. doi:10.1007/s10691-016-9323-y.

Lammasniemi, Laura. 2016. The benefit cap and the complexity of discrimination: R (SG and others) v Secretary of State for Work and Pensions. Feminist Legal Studies. doi:10.1007/s10691-015-9302-8.

Levers, Leanne. 2016. Review of Benedetta Faedi Duramy. Gender and violence in Haiti: Women's path from victims to agents. Feminist Legal Studies. doi:10.1007/s10691-016-9320-1.

Lloyd, Chris. 2016. Review of Marianne Constable. Our word is our bond: How legal speech acts. Feminist Legal Studies. doi:10.1007/s10691-016-9315-y.

Marti, Gabriela. 2016. Review of Zahra Meghani (ed). Women migrant workers: Ethical, legal and political problems. Feminist Legal Studies. doi:10.1007/s10691-016-9319-7.

Matulewicz, Kaitlyn. 2016. Law's gendered subtext: The gendered order of restaurant work and making sexual harassment normal. Feminist Legal Studies. doi:10.1007/s10691-016-9322-z.

McGuinness, Sheelagh. 2015. A guerilla strategy for a pro-life England. Law, Innovation and Technology 7(2): 283-314. doi:10.1080/17579961.2015.1106108.

Merry, Sally Engle. 2016. The seductions of quantification: Measuring human rights, gender violence and sex trafficking. Chicago: University of Chicago Press.

Seigworth, Gregory, and Melissa Greig. 2010. An inventory of shimmers. In The affect theory reader, ed. Melissa Greig and Gregory Seigworth, 1-25. Durham: Duke University Press.

\footnotetext{
5 Submissions to Feminist Legal Studies may be uploaded here https:/www.editorialmanager.com/fest/ default.aspx.
} 